\title{
ACCOUNTING FOR HYBRIDITY: ACCRUAL BUDGETING IN THE DUTCH CENTRAL GOVERNMENT
}

\author{
Nico P. Mol and Johan A.M. de Kruijf
}

\begin{abstract}
In the Dutch central government (following countries like New Zealand, Australia and the UK) a system of resource budgeting is being developed as a substitute for its present dual system of cash/commitment budgeting for core departments and accrual accounting for executive agencies. Advocates of this approach claim that resource budgeting will improve the allocation of government spending and increase efficiency in government production. A basic flaw of the reform proposals is the failure to acknowledge the hybridity of government activities and the need to accommodate these hybridities in the accounting system. We argue that the present dual system, with some minor revisions, will be superior to the proposed resource budgeting system.
\end{abstract}

\section{INTRODUCTION}

In his Budget Memorandum 2001 the Dutch Minister of Finance announced the replacement, effective in 2007, of the central government's present cash/commitment accounting system with an accrual accounting system. Similar reforms have occurred in New Zealand, Australia and the United Kingdom. At state and local levels in the USA, a shift towards accrual accounting is realized with the introduction of GASB 34. In general, the reform is driven by the motive to enhance efficiency in government, in accordance with the ideas developed under the heading of "new public (financial) management."

* Nico P. Mol, Ph.D., is Professor of Public Financial Management, Faculty of Business, Public Policy and Technology, University of Twente and the Royal Military Academy in the Netherlands. Johan A.M. de Kruijf, is Assistant Professor of Public Finance at the Faculty of Business, Public Policy and Technology, University of Twente.

Copyright $\odot 2003$ by PrAcademics Press 
The intended reform in the Netherlands will apply to both financial reporting and budgeting with accruals embedded in the budgetary accounts in stead of being working paper adjustments to produce accrualbased annual financial statements. Accrual budgeting, however, poses unique problems that reach beyond the widely discussed peculiarities of asset valuation (U.S. General Accounting Office, 2000). In the pursuit of accrual budgeting, fundamental differences between the concepts underlying budgetary and commercial accounting are involved that justify some general attention and analysis, which is the purpose of this paper.

The proposed use of accruals in government budgeting will shift the focus to the resources consumed rather than to the results obtained. This represents a restricted form of accrual accounting frequently characterized as "resource budgeting," in accordance with the label applied to the UK's reforms (White \& Hollingsworth, 1997; Likierman, 1998), that may be interpreted as a compromise solution between budgetary and commercial accounting. In this solution, authorized budgets should fulfill a dual function as both "ceiling on expenses" and "revenue earned" (Robinson, 2002, p. 88).

We believe that this quest for a compromise between budgetary and commercial accounting has some major flaws. The intended Dutch reform may be evaluated as an attempt to establish a degree of uniformity in accounting that denies rather than accommodates the hybridity inherent in government activities. In this paper, we will argue for a dual accounting system combining a cash basis for the core departments of central government and an accrual basis for its executive agencies.

The remainder of this paper proceeds as follows. First, some background information on the Dutch reform proposals is provided. Next, the contradictions between budgetary and commercial accounting implied in the proposals will be analyzed. Third, we argue the relevance of these contradictions, specifically with respect to levels of government which combine substantial powers to tax with substantial executive tasks in production (in the Dutch context, for central government contrary to supra national EU on the one hand and sub national provinces and municipalities on the other hand). Fourth, we describe the Dutch proposals in more detail, as they have been subsequently developed and 
adopted in the Budget Memorandum 2002 (issued September 2001). ${ }^{1}$ The two major objectives of the "resource budgeting" reform are scrutinized: (1) the objective to enhance a balanced decision making with respect to government investment and consumption and (2) the objective to generate accounting information on efficiency in government production. We argue the reform is flawed in both respects. Finally, the development of present Dutch central government accounting into a dual "hybrid" accounting system is proposed as an alternative.

\section{DUTCH CENTRAL GOVERNMENT ACCOUNTING REFORM}

Traditionally the Dutch central government uses a cash accounting and budgeting system. Since the 1980s when significant budget deficits occurred, the budgeting system also incorporates outstanding commitments. As a result, central government budgeting and accounting are predominantly tuned to the need for expenditure controls to help ward off such deficits. Hence, both commitments and disbursements are subjected to budgetary spending limits.

By the 1990s, with expenditure control firmly established, the efficiency and effectiveness of government performance became the prominent issue for political debate and the cash/commitment accounting and budgeting system was criticized on two points: (1) the crowding-out of investment by consumption induced by the system and (2) the lack of information about government efficiency generated by it. To address these concerns, budgeting and accounting were modified in two respects. To protect investment - specifically in the physical and economic infrastructure of society, considered neglected during the 1980s - two investment funds were created (the Infrastructure Fund and the Fund for the Strengthening of the Economic Structure), to earmark certain revenues for investment purposes within the present cash/commitment budgeting and accounting system. Central government expenditure on investment may now be budgeted either from these specific funds or from the general budget (for criticisms, see Boorsma and Mol, 1997).

To measure efficiency, government agencies involved in the supply of goods and services were required to provide information on costs and revenues. For these agencies, the possibility of accrual accounting was established in 1994 in an amendment to the Government Budgeting and Accounting Act 1976. As a consequence, two accounting systems presently co-exist in central government. 
According to Budget Memorandum 2001, the introduction of accrual accounting "government wide" could make both partial solutions superfluous. We will argue, however, that this "general solution" represents mere window dressing. It does not address the hybridities inherent in government activities, as our analysis of this attempt to reconcile the characteristics of budgetary and commercial accounting will reveal.

\section{ACCOUNTING SYSTEMS}

In budgetary accounting, the fundamental question to be answered is "How do I keep track of my spending?" For governments, this question is induced by the origin of their income from taxation. Budgeted expenditure should be tuned to the tax income levied from society. The primary function of accounting is to provide accountability with respect to expenditure in accordance with the authorizations underlying the budget. When budgets are derived from tax income recognized in cash receipts, accounting for expenditure on a cash basis (as disbursements) will establish a direct linkage between annual income and expenditure. Alternatively, however, budget authorizations may be framed in modified cash or commitments. Expenditure then would have to be accounted for accordingly.

On the contrary, in commercial accounting the fundamental question is "Are the revenues I receive sufficient to generate an income?" This point of view is relevant in any situation where continuation of an organization is not guaranteed by an inexhaustible resource of funds, but has to be earned by creating a market for goods and services from which income can be generated. Commercial accounting is supported by accrual accounting systems, which provide the possibility to match costs and revenues and to account for the changes in values of assets owned by the organization. This is why accrual accounting constitutes "generally accepted accounting" in business administration.

Thus, in budgetary accounting income spending is the relevant activity to be monitored, while commercial accounting focuses on income earning. Perrin (1998, p. 10) confirms this emphasis on spending by stating that ex ante information is the more important issue in public sector budgeting - instead of ex post information on profits or losses in private business. The distinction may be further conceptualized in Table 1. 
TABLE 1

Conceptualization of Income Spending and Income Earning

\begin{tabular}{|l|l|l|}
\hline & Income spending & Income earning \\
\hline With respect to & Consumption & Production \\
\hline Aiming at & Allocation (utility) & Efficiency (value added) \\
\hline By & Budgeting & Pricing \\
\hline In & Budgetary accounting & Commercial accounting \\
\hline Focusing on & Ex ante budgets & Expost accounts \\
\hline Specifying & Availability for spending & Results obtained \\
\hline By & Authorization of expenditure & Matching revenue and cost \\
\hline
\end{tabular}

As levying and spending tax income for public consumption primarily characterize economic behavior of government, budgetary accounting will determine its basic accounting system. This system should specifically apply to the legislative budgets of government. Executive government appropriates these budgets in accordance with authorizations by the legislative bodies of government. Spending should be accounted for in relation to these authorizations. Neither the realization principle nor the matching principle of business administration can be applied. Utilities to be derived from expenditure are not expressed as "revenues" in the accounts. Matching cost and revenue in terms of these utilities can thus assess no "value added."

In budgetary accounting, the principles of authorization and compliance are the relevant substitutes for the realization and matching principles of business administration. The authorization principle may be interpreted as the counterpart of the realization principle. The compliance principle will fulfill the role of matching actual expenditure to this budget.

We may note that budgetary accounting on a cash (or modified cash) basis can be deficient because it does not account for commitments prior to the actual expenditure of budgets allocated. Therefore, cash accounting may be supplemented by accounting of commitments to strengthen expenditure control - as is presently the case in Dutch central government. However, such amendments to cash accounting do not alter the basic objective of budgetary accounting to monitor income spending. Commercial accounting aiming at the determination of income earned does not contribute to this purpose and may thus be considered irrelevant from the point of view of legislative budgeting. 
Nevertheless, in the production of goods and services by government, efficiency may become a leading objective. The determination of "value for money" will then become essential. As a result, some reconciliation between budgetary and commercial accounting is needed. Consequently, a distinction between the allocation of resources to public programs in accordance with (social) utilities and the use of resources in the activities of government itself is also needed.

\section{CONSUMPTION AND PRODUCTION IN GOVERNMENT}

Public (legislative) budgeting focuses primarily on public consumption: the supply of public goods and services by spending government tax income, as opposed to the consumption of individual goods by the citizens themselves. Incidence of production of these public goods and services is an issue of secondary concern. Production may be outsourced to the private sector or to autonomized government agencies. Whenever supply is paid for by taxes, accountability with respect to public goods and services ultimately consumed will prevail. However, hybridity may arise here in two respects: (1) if public consumption is provided through government production, efficiency in production may be as relevant to the taxpayers as getting their money's worth for the goods and services in the public package, and (2) governments may supply products produced under the budget and the market mechanism simultaneously.

The actual relevance of these hybridities will depend upon the specific characteristics of public finances in governments. From the perspective of the Netherlands, we have to distinguish the supra national level of the European Union (EU), the national level of Dutch central government and the sub national level of the provinces and municipalities.

At the level of the European Union, income is nearly exclusively derived from upward tax sharing and expenditure consists overwhelmingly of transfer payments. Efficiency in EU production may therefore be considered of little importance. The need to include elements of accrual accounting at this level of government is negligible. On the contrary, problems in enforcing compliance in income spending call for a strengthening of budgetary control mechanisms.

At the sub national level the reverse holds true. More than $80 \%$ of local Dutch government's income is generated through transfers from the 
national government and only $8 \%$ is generated by taxation (mostly real estate property tax). Moreover, local taxation is subject to strict regulations set by central government. Consequently, it is nearly impossible to cover deficits with additional taxation.

The high dependence on grants implies that "balancing the budget" is the main financial management objective in local government. Not surprisingly, this objective has been codified as such by a legal requirement in Local Government Act 1992 and is monitored by provincial and national government. In view of this requirement, accounting information with respect to income earned - surpluses or deficits of revenues over costs - will be more fundamental than information on the specific purposes of income spent. To ensure the continuity of local government's supply of goods and services, local governments need an accrual accounting system in order to monitor the preservation of their assets. $^{2}$

Similar arguments apply at the national level to the autonomized governmental organizations created in the Netherlands in considerable numbers since the 1980s (Van Thiel, 2000, pp. 5-7). Generally, for these organizations, income is based on the provision of products and services to or on behalf of the central government. Since these autonomized governmental organizations usually have no legal basis to levy taxes, they should also use the accrual accounting system.

In contrast, the Dutch central government exemplifies the hybridities distinguished above. Government expenditure does cover central government production for about $20 \%$ - enough to raise questions with respect to efficiency of production in the executive agencies involved, but not enough to make this efficiency the major concern in public finance. Income is derived to a large extent from taxes - but not exclusively. Non-tax revenues, revenues from sale of assets and services specifically, encompass substantial amounts of money. Hence, it is rather evident that adjustment to these hybridities is a matter of some concern at this level of government.

The Dutch quest for a governmental type of accrual accounting may be recognized as an attempt to maintain uniformity notwithstanding the increasing variety of activities central government performs. The intended budget reform may exemplify a general attempt to harmonize hybridity and uniformity requirements and is discussed in the next section to assess its potential. 


\section{ACCRUALS IN DUTCH CENTRAL GOVERNMENT BUDGETING}

The intentions expressed in the Budget Memorandum 2001 (dating from September 2000) were further developed in a report, "State of the Art Budgeting," issued by the Department of Finance in July 2001. In this report the two main objectives of accrual accounting stated in the Budget Memorandum 2001 - to prevent crowding-out of government investment by consumption and to improve efficiency in government production - are reconfirmed. With respect to these objectives, the necessity to distinguish between current and capital expenditures is emphasized, as well as the relevance of full cost calculations including depreciation and capital charges.

Nevertheless, commitments will continue to be authorized in legislative budgets, and cash limitations will continue to be imposed in view of the (European) Economic and Monetary Union (EMU) deficit requirements and liquidity planning. Moreover, the report presumes that for about $97 \%$ of central government expenditure the equation "cash $=$ cost" will hold. Thus accrual accounting will be relevant for only about 2 billion euro in the yearly budget.

Notwithstanding widespread doubts on the benefits of the substantial administrative adaptations required by the reform, the proposals in the study were adopted with only one minor amendment in Budget Memorandum 2002 (September 2001). The year 2007 has been set as a target for the full implementation of the reform.

Basically, the reform will just imply an adjustment of capital expenditure to express capital cost in the budget. Current expenditure on personnel and material and transfer payments will remain to be recognized on a cash basis. An example presented in the "State of the Art Budgeting" report (Ministry of Finance, 2001) may clarify the intended accrual budgeting in the reform. In this example, a budget for purpose $\mathrm{X}$ (budgets are distinguished in a program format) in fiscal year $t+1$ might consist of:

$\begin{array}{ll}\text { - Personnel (current costs) }= & 30 \\ \text { - Material (current costs) }= & 10 \\ \text { - Depreciation }= & 2+2+0.4+2+1 \\ \text { - Capital charge }= & 0,6 \\ \text { - Non-ESA investment }= & 35 \\ \text { - Subsidies (transfer payments) }= & 50\end{array}$


In the budget, current costs of personnel and material as well as transfer payments and investments not recognized as such according to the European System of Accounts (ESA) will be accounted for on a cash basis. Adjustments to cash are limited to ESA capital, for which depreciation and capital charges will be included in the budget.

The calculation of these charges is explained in the report as follows. Depreciation is based on an amount of ESA recognized investments of 10 per $1 / 1$ year $t$ and 10 per $1 / 7$ year $t$, both with an economic life span of 5 years, with a current purchasing power adjustment of $2 \%$ of asset value per 31/12 year $\mathrm{t}$ (we may note here an error in the calculation presented: 0,4 is the full amount of the revaluation, not the additional depreciation to be derived from it), plus an amount of intended ESA recognized investments of 10 per $1 / 1$ year $\mathrm{t}+1$ and 10 per $1 / 7$ year $\mathrm{t}+1$, both with an economic life span of 5 years. The capital charge is calculated as $0,6=$ $4 \%$ of $(10+10 *(6 / 12))$.

The first question of our investigation of the reform will then be to what extent the advantages attributed to accrual budgeting generally will be preserved in these adjusted expenditure calculations. Secondly, the ambiguities in the concepts of expense and expenditure underlying these adjustments will be addressed.

\section{EVALUATION OF THE REFORM}

According to Budget Memorandum 2002 the proposed calculation of capital costs will provide the possibility to assess full costs of government activities. The determination of full costs is considered the key driver in the reform to both objectives of efficiency improvement and enhancement of government investment. The relevance of full costs to these objectives, however, is both misconceived and overstated. A misconception occurs in the argument that the calculation of capital costs will enable the assessment of life cycle costs for investment proposals. This is obviously not the case since future maintenance costs are left out of the calculation. Moreover, investment appraisals should be based on (present values of) future flows of costs and benefits rather than annual charges for the initial investment expenditure. Second, it is being suggested that the reform would enable the calculation of full costs of production. However, in the budget, only resource costs for program categories are involved. Thus the budgetary accounts will express costs of personnel, material and capital but not costs of production: 
government production involved in the program is not being measured for the program as such; only a set of indicators for intended outcomes will be provided. The contribution of the reform to the improvement of efficiency - if any - will necessarily be restricted to economy gains derived from annual cost rather than total expenditure comparisons with respect to capital outlays themselves.

Apart from these misconceptions, the relevance of the intended full cost calculations is being overstated. Generally, these calculations will be of limited relevance for decision-making; as in any decision only avoidable costs with respect to the issue decided upon are considered. So in budgetary decision-making, capital costs will only be avoidable in the initial decision on the investment. This might be the first budget year to which the capital costs of the investment are charged, but usually investment decisions will be made long before actual costs are incurred. Hence, the existing (Dutch) practice of accounting for commitments handles this adequately. Indeed, in the reform, only cash accounting is at stake, the present system of accounting for commitments - unknown in commercial accounting - will be continued. Evidently, the allocation of expenditure to investment and consumption purposes, respectively, will not be determined by the capital costs in the annual budget, but to a large extent by the obligations incurred.

Furthermore, substantial capital outlays are excluded from the capital cost calculations. First, subsidies may consist of capital transfers instead of income transfers, but will nonetheless be budgeted according to cash disbursements. Thus the misallocation between consumption and investment to be amended by the reform may result in a new distortion between central government investments and decentralized investments financed by capital transfers.

Similar distortions are involved in the distinction of ESA and nonESA categories of investment. In itself, the choice for ESA to separate capital from current expenditure is rather to be expected, as ESA is already underlying the EMU requirements for public sector budgeting. As government accounts are set up according to ESA definitions and principles to assess surpluses or deficits in view of EMU deficit limitations, the same definitions may be used to determine relevant investments and the same principles to assess asset values for those investments. The application of ESA - contrary to the International Public Sector Accounting Standards (IPSAS) - is thereby defended in the State of the Art Budgeting report because of the detailed guidelines 
specified in this system. To guarantee sound budgetary behavior very specific principles for asset valuation are needed. In this respect IPSAS are considered too vague.

However, precision in the definition of capital expenditure provided by ESA may counter validity. Thus, some categories of government investment may be unintentionally excluded from ESA definitions. Specifically weapon systems for defense are defined as "government consumption" - presumably alright from a macro-economic point of view, but somewhat awkward with respect to the intended improvement of efficiency and allocation to consumption and investment purposes. In the UK - not subject to EMU regulations - investments in defense are indeed included as capital expenditure in the resource budgets, notwithstanding the necessary reconciliation of the accounts to ESA for external reporting purposes (U.K. Ministry of Defense, 2001 pp. 27-28).

Generally, the detailed guidelines provided by ESA are not specifically tuned to the characteristics of capital owned by government, as this defense example illustrates. In the past, the Dutch minister of Finance has stressed the distinct characteristics of government investments in "the physical, economic and social infrastructure" provided by government. In considering any expenditure as a social investment, a wide range of arguments may be brought to the fore. Ultimately, the attribution of future social utilities underlying the creation of social capital will be politically determined.

The decision to apply a specific principle to distinguish between current and capital expenditure is and should be a political one. The narrow interpretation forced upon government by the application of the ESA definitions, combined with the exclusion of capital transfers from these definitions in central government budgeting (contrary to the inclusion in the consolidated public sector accounts in determining the relevant EMU deficits) explains the nearly negligible 3\% of the budget actually affected by the reform (cf. Guthrie, 1998:13-14, on the potential significance of the differences between cash and accrual based allocations of financial resources). With this percentage in mind, a number of issues are raised with respect to the complicated administrative adjustments involved in the reform. Obviously, the calculated depreciation and capital charges introduce a lot of bookkeeping, not representing any decision making in the budget. The transparency of the authorizations in the present cash/commitment 
accounting system (both expenditures and obligations are clear-cut objects of decision making) is thereby impaired. From this perspective we will discuss these adjustments in more detail in the next section.

\section{DETERMINATION OF CAPITAL COSTS}

In accordance with ESA, capital costs will have to be based upon some 'actual value' asset valuation, contrary to IPSAS 17 and GASB 34 which use historic cost. From this valuation, subsequent depreciation and capital charges will be derived. This orientation at actual values also opposes the present historic cost valuation requirements in (Dutch) sub national government and in the accruals using agencies in central government itself. Apart from this confusing idiosyncrasy, the assessment of actual values will pose a lot of difficulties for the central government assets involved.

The solution proposed encompasses a choice between actual market values - whenever they can be assessed - or inflation adjusted historic costs (implying a variety of current purchasing power accounting). We will discuss this solution from two perspectives: (1) the arbitrariness and the need to establish an independent supervising authority to monitor its application, and (2) the relevance with respect to decision-making.

To apply market based (actual) valuations, it is necessary to assess the relevance and precision of available market prices on a case-by-case basis. Obviously, budgetary implications may lead to strategic behavior in these assessments. Here - and in other unsolved issues in the application of accrual accounting - the deus ex machina of an "independent supervising body" is invoked. Fears of manipulated statements are such that doubts are being expressed if even the Court of Audit - working on behalf of parliament - would be sufficiently independent to fulfill this task.

The independence sought can only be provided by private accounting supervisors, as established in New Zealand and the United Kingdom (White \& Hollingsworth, 2001, pp. 52-53). Such supervisors will have to comply to the International Accounting Standards (IAS) developed for the private sector, in which social - non-financial - benefits will be excluded from the valuation, even where they are decisive for the upkeep, replacement or sale of the assets involved (cf. Lundquist, 2001, p. 28, challenging IAS 36 in this respect). Asset valuation based upon irrelevant actual market values will impair the transparency of the 
accounts to the political decision makers for whom those accounts are primarily intended.

Apart from the peculiarities of government assets, valuation in accordance with IAS to determine capital costs in government budgeting may be critized from the financial accounting/management accounting distinction (Jones, 1998, pp. 13-14). The ultimate (management accounting) objective to determine costs of services provided will not benefit from the restrictions imposed by this (financial accounting) framework for an independent asset valuation.

Robinson (1998a) discusses in general terms the decision relevance of the application of actual values in determining cost of capital. To reflect opportunity costs, assets should be valued at net realizable value. The intention to use actual value or current purchasing power accounting instead implies incorporating substantial sunk costs in budgeted capital costs. In the end however, the relevance of actual value or current purchasing power accounting is defended by Robinson based on the concept of "intergenerational equity." According to Musgrave and Musgrave, this criterion is specified as "the 'golden rule' that tax payers in each time period should finance all current expenditure and should make a contribution to the financing of inherited productive assets commensurate with the benefits they receive from those assets" (Musgrave \& Musgrave, 1973, p. 607). From this conceptualization, Robinson infers that "spreading the costs of such assets over their lifespan implies that valuation methodology should be based upon the actual cost (in real terms) of productive assets" (Robinson, 1998a, p. 32).

In our view, this inference is invalid. Taxation for investment purposes imposes a burden for the lifespan of the capital involved, but not necessarily beyond this period. In principle, future generations may decide again if they want the capital to be replaced - and burden themselves at that moment with the financing of those replacements. Thus, in the investment decision only the authorized capital expenditure is at stake. Valuation in accordance with historic costs will ensure that the golden rule is observed.

Subsequent to the issue of asset valuation the derivation of depreciation and capital charges from asset values may be discussed. The intended capital charges may be considered as purely 'nominal,' unless they represent opportunity costs with respect to the use of capital (Robinson, 1998b). 
Charges for the use of capital should not be applied to all assets (legally) owned by government, but only to those (economically) used in the production of government services. The calculation of depreciation and capital charges with respect to all ESA recognized investments - and the neglect of user costs for all non-ESA capital expenditure - does not satisfy this requirement.

ESA explicitly separates assets on the basis of legal ownership. Accordingly capital charges should be budgeted for government participations valued as assets on the government's balance sheet (government owned companies like Schiphol Airport etc.) as well. Obviously, no authorization to spend income is implied in such budgeted capital charges at all.

Nominal (administratively determined) capital charges in budgets obscure the authorizations ultimately transmitted through those budgets. These charges thereby may have disturbing consequences from a legislative point of view. They do not represent objects of decision making for which executive spenders may be held accountable. They are strictly non-controllable; compliance to the authorizations may only be observed in a purely formal sense.

With respect to capital ownership, resource costs will be determined for the economic lifespan of the assets when the investment decision is being made. Budgeting for capital expenditure will therefore have to address capital expenditure itself. Authorization of investment may then be directly aimed at the long-term decisions involved by separating capital budgets from current ones - as exemplified by the creation of investment funds in present Dutch central government budgeting.

Additionally, capital budgeting is necessary in any case in view of expenditure control. Decision-making in central government on investment is subjected to the overall expenditure margins determined by the EMU deficit limit and the zero deficit targets actually preserved in the Netherlands.

\section{ACCOUNTING FOR RESOURCES AS A CONCEPT OF ACCRUALS}

Notwithstanding all adjustments to assess capital costs, in the "State of the Art Budgeting" report (Ministry of Finance, 2001) the issue of accrual cost calculation is being rigorously simplified: (Cash) expenditure on all personnel and non fixed material resources is 
immediately identified as "costs." Obviously, substantial accrued expenses in government production may be ignored in this simplified accounting system. We doubt that the reform will substantially contribute to an improved efficiency in this production.

This simplification may be criticized more fundamentally with respect to the conception of "accruals" implied in the current/capital distinction. Because this distinction applies to resources and not to activities, values created or lost through these activities cannot be recognized. The matching and realization principles binding resource costs to revenues cannot be applied to the 'current costs' calculated within the intended resource budgeting system. Values added cannot be assessed. Thus we may justly question whether the label 'accrual accounting' is misleading when applied to this reform as well as to the similar systems of resource budgeting in Australia, New Zealand and the UK. We develop our argument starting from the definitions of accrual accounting presented by the International Federation of Accountants (IFAC) Public Sector Committee that might constitute the basis of these reforms.

The development of IPSAS by the IFAC Public Sector Committee has already been thoroughly criticized by Chan (2001). Specifically we join him in his remark that "the IPSAS has emphasized financial accounting and external reporting to the neglect of budgeting" (Chan, 2001, p. 2). Obviously, accrual accounting may be applied to financial reports independently from budgets eventually underlying financial decision-making. Thus efficiency may be assessed in ex post benefit-cost comparisons, regardless of judgments on legitimacy to be derived from compliance audits with respect to the decisions involved. IPSAS can thereby provide the guidelines for financial reporting, while budgetary accounting remains in vigor to establish compliance with authorized budgets.

Contrary to our analysis presented above, however, Chan (2001, p. \# for quotes] characterizes budgetary accounting as emphasizing "executive accountability to legislature" - in opposition to "accountability to the electorate and general public." Commitments and cash flows are considered by him as key financial measures in the first type of accountability, accruals in the last. Obviously, tuning government accounting to the electorate and the general public may be acknowledged a relevant objective. In his view, accrual accounting as such should not 
be discussed but, rather, the neglect of government cost characteristics in the International Accounting Standards Committee (IASC) model underlying the IPSAS proposed: "the public goods nature (...) in addition to the government's power to tax makes it difficult, if not impossible, to recognize revenue on the basis of services rendered to individual tax payers" (for similar conclusions with respect to U.S. GASB and the choices made in GASB 34 to maintain financial resource measurement for government funds (Chan, 1999, pp. 378-379; Patton \& Been, 2001, p. 35).

As Chan acknowledges, taxes, as non-reciprocal transactions, may be based upon equity rather than efficiency considerations. What kind of accruals, then, could Chan have in mind? Clearly, matching of costs to (tax) revenues will be impossible and irrelevant in that case.

In our analysis taxpayers will not try to establish the efficiency results of their tax contributions but the utilities to be derived from alternative spending objectives for these contributions. These objectives are specified in the programs for which budgets are being authorized. In accordance with these budgets, utilities to be derived from and contributions paid for these programs may be matched with each other comparable to the decision making of the individual taxpayer with respect to his own consumption of his expendable income. Thus compliance to allocated budgets will not only be the primary focus of accountability for the legislature, but for the electorate and the general public as well.

In our view, the cash versus accruals debate with respect to IPSAS is biased by the definitions of accruals applied in the standards proposed. In the IFAC PSC definitions full accrual accounting is defined as accounting for economic resources (and changes therein) instead of the financial resources considered in cash, modified cash and restricted accrual accounting respectively. Accrual accounting is thus identified (by definition) with resource accounting - notwithstanding the failure to apply the realization and matching principles in all tax financed government activities being accounted for. In our view accounting for accruals should imply some assessment of value added in the use of resources. A distinction between resources consumed and resources transformed into other assets may only be derived from an investigation of the benefits resulting from their utilization. 
Thus the cost concept can only be used in a system of resource accounting in a restricted sense. Cost accounts involved will only address these resources themselves (expenses on personnel and material), not the costs of the production eventually obtained.

\section{UNSOLVED HYBRIDITIES}

Resource budgeting will be deficient from both perspectives of budgetary and commercial accounting. In budgetary accounting, compliance in decision making with authorizations should be assessed. Thus accounting should fulfill a transparency criterion to derive unambiguously the decisions to which the executive is being entitled by the legislator. Accounting for commitments cannot fulfill this requirement on its own, because of the (long term) uncertainties with respect to the precise amounts of money involved in the future and their incidence in annual budgets then. Accounting for expenditure has to join the commitments to authorize direct spending. Obviously, accounting for costs will not enhance this compliance - as is being acknowledged in the condition that cash accounting will have to be maintained in view of EMU budget limitations and resource control. Authorization requirements are thus not fulfilled in the resource budgets, neither with respect to controllability nor with respect to transparency of the budget.

Matching requirements from the perspective of commercial accounting are also not met in the application of resource budgeting. Expenses (adjusted expenditure on resources) are not matched to benefits (revenues) to obtain any evaluation of efficiency on resource consumption. Deficiencies symptomatic for cash accounting like the spending drive towards the end of the budget year will not be repaired by this reform. As the examples of Australia and New Zealand clarify, budgeting of adjusted expenditure remains budgeting for expenditure (Robinson, 2002). The benefits of resource budgeting will thus be limited to the assessment of full costs for a restricted category of capital outlays. The price to pay for these benefits - in terms of controllability and transparency - is high.

Recent awareness of the deficiencies in the concept of accruals underlying the intended Dutch reform has emerged. In March 2002, the label of accrual accounting was replaced by 'state of the art budgeting' in the internal documents produced in the implementation process within Dutch central government. Moreover, the consequences of the necessity 
to conceive expenses as adjusted expenditures in budgetary accounting are acknowledged: specifically, the original expectations that the reform would end the end-of-year spending drive have been given up (as reported on the basis of evidence gathered by the Dutch department of Finance in Australia and New Zealand).

In the State of the Art Budgeting report a significant amendment was implied. Contrary to the intentions in the Budget Memorandum 2001, the dual system, including a differentiated accounting system in executive agencies, will be maintained. For the agencies, asset valuation will be based on (unadjusted) historic costs, in accordance with private sector practices and regulations for sub national government in the Netherlands.

These hesitations may pave the way for some reconsideration of the reform, and a revaluation of the potential of the present system. In our view the objectives of controllability and transparency on the one hand and effective allocation and efficient production on the other hand may be reconciled in this accounting system, by distinguishing systematically between current and capital expenditure in the budget and by redefining core government to agency relationships. Starting from an exposition of the major flaws of the present system we will try to argue our proposition that some minor corrections will suffice to adapt it to these objectives.

\section{HYBRIDITY IN GOVERNMENT ACCOUNTING}

In the introduction we touched upon the two partial solutions provided in the present Dutch central government accounting system to the deficiencies of cash/commitment accounting: (1) the creation of investment funds to counter the perceived crowding-out of investment by consumption and (2) the application of accrual accounting in governmental organizations provided (by law) with an 'agency status'. The Minister of Finance initially defended both of these partial solutions in his 1997 memorandum entitled "From Expenditure to Cost" (Ministry of Finance, 1997) (which he later denounced in his 2001 Budget Memorandum). In that memorandum, he argued that capital investments - as recognized in business accounting - are not equal to expenditure for sustainable economic growth. The minister acknowledged that social investments like education do not coincide with the definition of capital expenditures agreed upon in the European System of Accounts, and that accrual accounting based on ESA would thus not optimize budget allocation from a social point of view. Furthermore, the minister argued 
that accrual accounting would not make fiscal policy more transparent and would bias expenditure on investment in favor of national investment instead of capital transfer for investment purposes at decentralized levels of government. Notably, one of the justifications underlying the creation of special investment funds was, in his view, to optimize allocation of investments between national and local or regional levels. Thus, according to his 1997 memorandum, governmental capital expenditure should acknowledge all investment in "the physical, economic and social infrastructure" provided by the government to society.

Obviously, however, this requirement is not met by the present (partial) investment funds. These funds provide capital almost exclusively to projects with respect to the physical infrastructure, covering investment related to traffic and transport specifically. To fulfill the objective of the finance minister's 1997 memorandum, a systematic distinction of capital from current expenditure is required.

Such a distinction of types of expenditure may easily be framed within the present cash/commitment accounting system (in fact it has been general practice in Dutch central government accounting until the adoption of the Budgeting and Accounting Act 1976). The criteria to be applied in such a separation should thereby constitute objects of political decision-making. Social circumstances may determine which type of expenditure may be classified as capital expenditure and be treated in budget allocation accordingly (after the Second World War, e.g., a capital account for "reconstruction," which has existed until 1958, was established in the Netherlands).

In our view the present cash/commitment accounting system may thus be amended by the separation of current and capital accounts. Governing political party coalitions may specify the criteria to be applied in the Governance Agreements underlying their cooperation.

In the 1997 memorandum the second bias mentioned in our introduction - the absence of information on efficiency - did not arise. It was assumed (by the minister of Finance) that the newly created agency status would provide an adequate solution to this bias, as agencies (in most cases comparable to US internal service funds) were required to apply full accrual accounting. 
Nevertheless, the efficiency improvements to be derived from the agency contracts were being contested by many observers. The contractual negotiations implied in the department-agency relations were often characterized as "playing a game." Not the intended demand and supply relationship with the core departments, but the hierarchical subordination to these departments dominated the controls applied to agency activities. Notwithstanding the accounts for revenues and costs of their services, budgeted expenditure remained the primary focus of these controls.

In our view, the deficiencies observed in agency performance cannot be attributed to the agency status per se. Deficiencies in agency accounting requirements may be held responsible for them instead. The accounting systems imposed on the agencies only partially represent accrual accounting as applied in business. To a large extent elements of budgetary accounting remain in vigor, specifically with respect to authorization requirements for agency "expense."

These authorization requirements are derived from the principle that all government expenditure should be authorized. As agency revenues may partly consist of third party payments for services delivered, expenditure of the income thus generated should be authorized separately, in addition to the authorization of departmental spending on agency services. The solution to this authorization problem actually implies that agency expense budgets are authorized apart from departmental expenditure budgets (with some consolidated statement harmonizing expense/expenditure differences). In fact, agency expenses are subjected to a twofold authorization when they are paid for by central government itself: first, by authorization of expenditure in core departments on the agency services, and second by the authorization of the expense incurred in the agencies themselves.

Recognition of the hybridity implied in these twofold authorizations may suggest a more efficient solution. Authorizations with respect to third party payments might address those payments themselves: agency contracting may be subjected to authorizations with respect to potential clients and types and tariffs of services - and revenue generated from those services may be earmarked for their production. Additionally, of course, revenues from core government are already authorized through central government budgets. Thus, commercial accounting for the agencies does not have to be contaminated by any budgetary accounting 
for their "expenses." No direct authorizations are required with respect to the costs incurred in their production.

Contrary to resource accounting, full accrual accounting may then be applied to producing business units in government to assess value added (results obtained) in the actual supply of their services. Instead of a uniform system of resource budgeting to be applied in all government organizations, a consistent dual system of cash/commitment accounting for core government and accrual accounting for executive agencies will thereby be obtained.

In such a dual accounting system value for money from government production can be analysed with respect to effectiveness (utilities derived from budget spending) and efficiency (agency results in terms of revenues and costs). In the intended resource budgeting system no information on efficiency but only on economy - expense instead of expenditure for the means of production - will be provided.

\section{CONCLUSION}

In conformity with similar reforms in New Zealand, Australia and the United Kingdom, the Dutch central government will replace its present cash/commitment budgeting with a system of resource budgeting. From this reform politicians expect an improvement in budgetary allocation on investment in government spending and an improvement of efficiency in government production. We argue that this reform ignores the hybridity of government in spending tax income on the one hand and creating value added on the other hand. Accounting for this hybridity requires a combined (dual) application of budgetary and commercial accounting, not a compromise solution between these two systems. With some minor adjustments, the present Dutch accounting system of cash/commitment accounting for government core departments and accrual accounting for executive agencies, may meet these requirements adequately.

\section{NOTES}

1. A new government coalition (formed after elections in May 2002) formally endorsed the proposals in its budget memorandum 2003. However, this coalition had to resign already in October and new elections will be held in January 2003. Further developments in the 
implementation process are not expected before a new minister of Finance will take office after these elections.

2. Unlike American local governments, a Dutch local government cannot go bankrupt due to specific provisions in the financial relations between central and local government. The assessment of the financial position by financial intermediaries, which is one of the arguments for introducing GASB 34, is therefore of only limited relevance.

\section{REFERENCES}

Boorsma, P.B., \& Mol, N.P. (1997). Capital budgeting in Dutch central government, Public Budgeting and Financial Management, 8 (4), 597-611.

Chan, J.L. (1999). The bases of accounting for budgeting and financial reporting. In Meyers, R.T. (Ed.). Handbook of government budgeting (pp. 357-380). San Francisco, CA: Jossey-Bass Publishers.

Chan, J.L. (2001, June). Global government accounting principles. Paper presented at the $8^{\text {th }}$ Biennial CIGAR Conference, Valencia, Spain.

Guthrie, J. (1998, February). Application of accrual accounting in the Australian public sector - Rhetoric or reality? Financial Accountability \& Management, 14 (1), 1-19.

Jones, R. (1998). The conceptual framework of resource accounting. Public Money \& Management, April-June 1998, pp. 11-16

Likierman, A. (1998, April-June). Resource accounting and budgeting Where are we now? Public Money \& Management, 17-20.

Lundquist, K. (2001). Accrual accounting in Swedish central government. Stockholm, Sweden: Ekonomistyrningsverket.

Minister of Finance. (1997). From Expenditure to Cost (Van Uitgaven naar Kosten). The Hague, the Netherlands: Ministry of Finance.

Minister of Finance. (2001). Budget Memorandum 2001 (Miljoenennota 2001). The Hague, the Netherlands: Ministry of Finance.

Minister of Finance. (2002). Budget Memorandum 2002 (Miljoenennota 2002). The Hague, the Netherlands: Ministry of Finance. 
Ministry of Finance. (2001, July 24). State of the Art Budgeting (Eigentijds Begroten). The Hague, the Netherlands: Author.

Musgrave, R., \& P. Musgrave (1973). Public finance in theory and practice. New York: McGraw-Hill.

Patton, T.K., \& Bean, D.R. (2001). Why and how of the new capital asset reporting requirements. Public Budgeting and Finance, 21 (3), 31-46.

Perrin, J. (1998, April-June). From Cash to Accruals in 25 Years, Public Money \& Management, 7-10.

Robinson, M. (1998a). Accrual accounting and the efficiency of the core public sector. Financial Accountability \& Management, 14 (1), 2137.

Robinson, M. (1998b). Capital charges and capital expenditure decisions in core government, Journal of Public Budgeting, Accounting \& Financial Management, 10 (3), 354-374.

Robinson, M. (2002) Financial control in Australian government budgeting, Public Budgeting \& Finance, 22 (1), 80-93.

Van Thiel, S. (2000). Quangocratization: Trends, causes and consequences Unpublished thesis. University of Utrecht, Utrecht, The Netherlands.

U.K. Ministry of Defence. (2001, January 31). Consolidated departmental resource accounts 1999-2000. London, UK: Author.

U.S. General Accounting Office. (2000, February), Accrual budgeting, experiences of other nations and implications for the United States,. Washington, DC: Author.

White, F., \& Hollingsworth, K. (1997, Autumn). Resource accounting and budgeting: Constitutional implications, Public Law, 437-445.

White, F., \& Hollingsworth, K. (2001, Spring). Public finance reform: the Government Resources and Accounts Act 2000, Public Law, 5061. 